\title{
"As Long As We Both Shall Live": In Which a Lesser Librarian Reviews His Reading Problem
}

By ARTHUR P. SWEET

\section{THE TESTIMONY}

Helen E. Haines (1935): “The spirit of delight and confidence in books, the receptive and adventurous attitude toward the new and the experimental, the broad catholicity of lifelong friendship and understanding for literature, should be attributes of librarianship more than of any other calling." 1

Lawrence C. Powell (1948): "We are traditionally too busy ordering, cataloging, giving out, and getting back books to have much time for reading them. We joke among ourselves about being too busy to read. This I deplore." "I think it is time for a revolution, for a return to fundamentals, the most elementary of which is the truth that books are written and published first of all to be read; and that as librarians, a favored people who hold custody of the world's permanent stocks of books, we should be the most avid readers on earth." 2

Ernest J. Reece (1949): "No questioning of librarians would have been necessary in order to learn that they are less than satisfied with the knowledge of books possessed by library staffs." 3

M. R. Sullivan (1949): “Tantalizing and tempting as the books may be, leisurely reading is something you sacrifice when you join a library staff. Whatever time you may be able to eke out for reading must be devoted, for the most part,

${ }^{1}$ Living with Books; the Art of Book Selection (New York: Columbia University Press, 1935) i D. 10.

2 "Librarians as Readers of Books," Wilson Library Bulletin, XXII (1948), 439-44.

3 The Task and Training of Librarians (New York: King's Crown Press, 1949), p. 26.
Mr. Sweet is Acquisitions Librarian, Cornell University Library.

to professional literature and book reviews." 4

Felix Reichmann (1953): “The knowledge of books is our source of intellectual energy; cut off from our spiritual mainspring, librarianship becomes a mechanical service unit in the lower brackets and at the very best a managerial function in the higher echelons."

"There can be no doubt that most librarians are vitally interested in books and are painfully aware of their lack of book-knowledge. Many recent experiences have shown that the library staff responded enthusiastically to every opportunity to broaden their knowledge. It is the duty of all of us to make this interest active."5

Howard A. Burton (1954): "That librarians should know more about books than their covers and the cards which locate them is easy to see, but it is not always so easy to see how this goal can be achieved. Libraries cannot depend on getting staffs made up only of devoted booklovers or of those determined to keep up with the best of current books; they cannot depend, that is, on the extracurricular ambition of their staffs. But at last the profession is becoming more acutely aware of the problem and is suggesting ways of solving it. Any effort to

" "You Have Such an Easy Job," Wilson Library Bulletin, XXIII (1949), 687-88

"Hercules and Antaeus," CRL, XIV (1953), 22-25, 34. 
prevent the disappearance of the wellread librarian is praiseworthy." 6

\section{RESTATEMENT OF THE CASE}

These remarks represent only a small portion of the testimony which can be adduced from expert witnesses to show that all is not well with the marriage of librarians and books. Books, through the agency of their producers and users, have been making such increasingly outrageous demands upon librarians that there is substantial evidence of the latter's retaliation by adulterous association with television. Divorce seems threatened; and it may be, even now, too late for this attempt at reconciliation.

What bothers me, as one of the principals in the case, is that these numerous, presumably older and wiser, critical observers have little to offer in the way of constructive guidance. They shake their heads sadly, admit that it is a very tough problem, tell me piously that it could be such a beautiful thing, and seem to feel that they have discharged their duty. In my desperate determination to preserve the sanctity of our union, I have had to find my own way, with very little benefit of counsel, through the conflict and confusion, towards some possible, practical solution; until, at last, I feel ready to conclude my separate peace and make my tentative, trial compact with the profession I love. In the hope that a full and frank statement of my adjustment may prove helpful to other alienated souls among my colleagues, even though they may disagree, I record my convictions.

A few basic propositions defining the problem appear to me to be either generally conceded or statistically demonstrable, so that they can be accepted as a starting-point:

1. Professional librarians, working in whatever capacity in whatever type and size of library, ought to have a wide con-

6 "Maximum Benefits from a Program for Staff Reading," CRL, XV (1954), 277-80. versance with the contents of books, over the entire range of recorded knowledge, plus a more intense acquaintance with the materials of one or more special fields, in addition to a familiarity with the major problems of all departments of librarianship. This, at least, seems to be our professional dogma.

2. In the practical sphere of job placement and recruiting, however, the neophyte librarian's knowledge of books, whether general or specialized, and his eternal dedication to the avocation of reading, are customarily assumed, without close examination; whereas, it is his mechanical skills and technical proficiencies, as measured by previous training and experience, with which the employers are primarily and minutely concerned. Thus, the number of languages he can boast, and his scholastic proficiency therein, are important considerations; the quantity and quality of reading he does in any of them, even-and especially-English, is immaterial and irrelevant.

3. In large research libraries, surely, (and, I suspect, in most smaller libraries, as well), the volume of business, the variety of materials, and the number of services to patrons increase year by year in greater ratio than the increase in staff. In part the disparity may be offset by more efficient methods or better plant and equipment; but such ameliorations cannot equate the entire disproportion. The very growth in the size of the collection creates new problems with which to cope.

4. From that high degree of specialization which is the principal demand upon, and source of "status" for, the professional librarian in the early stages of his career, the situation changes abruptly, midway up the ladder: exactly the reverse specification applies, and it is a broad knowledge of both books and professional problems which becomes vitally important. Library administration presupposes the wide range of experience

COLLEGE ANDRESEARCH LIBRARIES 
which departmental pressures and subject insularities make it difficult-often, all but impossible-for the librarian in lower echelons to obtain.

This, then, is the predicament in which the earnest young librarian with good intentions and high ambitions finds himself: His immediate economic welfare and his future professional reputation depend upon his willingness to devote more and more attention to a highly restricted segment of the total library function, and upon his ability to produce more and more "units" (bookscataloged, books-circulated, referencequestions-answered, etc.), by giving less and less attention to each one; yet he is perennially abused by his conscience, his public or private patrons, and his professional counselors, for his narrow interests, shallow learning, and superficial skills. He is given to understand that the higher he hopes to go in the profession, the more essential a wide range of academic competence becomes; yet his day-to-day responsibilities convince him that any such broad background will have to be achieved more in spite of his job than through its aid. Small wonder that he generally looks beyond himself for some resolution of this unenviable dilemma, and grows cynical when no satisfactory answer is forthcoming.

There are those who tell me that this problem is really nonexistent: purely imaginary. Most librarians, they say, do read, as much as is necessary; moreover, such "background" reading, unrelated to any immediate, practical problem, is of little real significance or professional value; and, finally, advancement is not actually dependent upon either breadth of experience or scope of book-knowledge. Unable to argue, I can only insist that my own admittedly limited experience, observation, and reading refutes this complacent optimism on every count.

There are others who, admitting the problem, would claim that there is no so- lution, unless it be Time and Luck; and the best thing is not to take it too seriously. But I am not willing to accept this counsel of defeat, frustration, and drudgery. I will readily concede that it must be, to a considerable extent, a personal response, varying in its particulars from individual to individual. Since my conflicting interests, personal tastes, professional goals, and present circumstances are not the same as yours, our answers will not be identical. Nor will there be a fixed and final answer, even for the individual quester: as his situation changes, for better or for worse, his program must modify accordingly. I will further concede that it will rarely be, for any of us at any time, an easy solution. It requires conviction and strength of purpose, the sacrifice of other inviting pursuits and activities, the use of stopgap methods, and a certain resistance to familial, community, and other social pressures; and none of these prerequisites is pleasant. Nevertheless, the way to a harmonious coalescence is there, for those who still can see their profession as something more than just a job.

\section{REFUTATION OF THE ALIBIS}

Faced with this need for a greater knowledge of books through a continuing program of personal reading, and with the realization that there is no ready-made, easy answer which will serve, where does one begin? I found that the first need was firmly and finally to lay the ghosts of a host of alibis which my own ingenuity or that of rationalizing co-workers promptly produce to prove that it is unreasonable to expect me to do much reading.

The foremost and favorite excuse is the old refrain: "No time for reading." This is obviously a vague evasion which, if pressed for explanation and justification, comes to some such conclusion as this: There are so many things outside of the workday routine which just have to be done; therefore, there is no time 
for reading,-much as I'd like tol (Always well to add that.)

Non sequitur: from a valid premise, a false conclusion. Certainly eating, sleeping, housekeeping, family ties, friendly associations, civic duties, etc., are all legitimate-if not inescapable-demands which make their several inroads on our so-called "free" time. To this some librarians might add a certain amount of gratuitous overtime on purely library matters. But there is implicit in this plea a certain confusion between two distinct types of imperative: natural law and social compulsion. Morally speaking, there may be as much "ought" in one as in the other; but the defiance of nature's requirements subjects us to far more severe sanctions than the avoidance of social pressures.

Most of the claims on our out-of-office hours are social claims; and it is a rare individual who is not exposed to more of these than any one person could possibly satisfy. A greater or lesser part of them will have to be rejected in any event; and, despite all self-delusion ("I really didn't want to, but I simply couldn't refuse"), it is still the individual who decides for himself how many and which ones will be undertaken, and which can be deferred, or evaded, or ignored. Here a significant law of human behavior becomes apparent: Whatever one eagerly and intensely wants to do, he somehow finds time to do. I shall not labor the point: the illustrations are all around you-even, if you will look with sufficient candor and clarity, within you. If the truly sincere addiction to reading is there, it will be served.

A further fallacy in this alibi is its failure to take any account of the factor of time-organization and efficiency. Even if it is taking all my unsold waking hours to accomplish $x$ number of personal and social functions, it may be because I am doing some of them inefficiently, or with unnecessary fastidiousness. By rescheduling sequences, grouping what can be combined, cutting unimportant frills, and giving a little unaccustomed thought to "ways and means," I may be able to do the same number of things equally well and still have time to spend in reading. Of course it is true that this kind of thinking itself takes time: time which I may again plead the excuse of not having to spare. But when an expenditure of, say, half an hour per day for just one week may net me an average gain of one hour for every day thereafter, I'd be foolish not to take the gamble. And, if nowhere else, there is always vacation: a wonderful time for such review, reassassment, and rededication.

Then, too, there is a surprising amount of otherwise waste time in anyone's days which can be salvaged by reading. Carry with you, in pocket or purse, a worthwhile paperback of your own selection, and discover how pleasantly you may pass those transitional times: riding on a bus, waiting your turn in the barber shop, or marking time until the dentist is ready for you.

But the "too busy" justification is only one of the many diabolical rationalizations there are to be reckoned with. Another one, subtly flattering to one's selfesteem, says: "Too tired to read"; because I put so much of myself into the day's work, I'm just too worn out at the end of the day for any intelligent reading. Here, I suggest a simple, mathematical approach: If you are working an average of more than eight hours per day, you'd better start looking for another job; if you are sleeping an average of more than eight or nine hours out of each twenty-four, you'd better see a doctor. If not, there are bound to be seven or eight other hours, not more than half of which can be spent in a state of utter exhaustion. With all due allowance for inescapable domestic routines, one or two of those hours must be available, some days, for reading. (I do not even speak of weekends, holidays, convalescences, etc.) Your only problem is to iden- 
tify them, and arrange your schedule for their exploitation.

Another excuse is what I call the "balanced-personality" alibi, which argues: All day long, every day, as a librarian I am working with books; on my own time I'm going to do other things, so that I don't turn into one of those bibliomaniacs who have nothing else in the world but books to talk about. The essential flaw in this thesis is its disregard for the significant fact that a librarian, all day long, every day, is busy doing things to books, which is quite a different matter from the leisurely reading of books of one's own choice. No librarian of my acquaintance spends any appreciable portion of his salaried time in reading for pleasure, or even for education; and I, for one, would like to know where such a job might be found. The lintotype machine operator might use this excuse for not reading with better logic than the librarian.

Moreover, there is no inherent reason why the practice of spare-time reading should preclude the pursuit of all other personal interests, as this particular contention implies it would. And it might be added that librarians, of all people, should be aware of the extent to which any other broadening and balancing interest-theater, art, photography, cooking, gardening, or bird-study-can be enhanced and enlarged by the judicious use of books.

A fourth "way out" is a materialistic reaction which may be termed the "showme-first-your-penny" alibi. It says: "The main reason for my needing to know more about books is so that I can do a better job; and that's the boss's problem; as far as I, personally, am concerned, there are other things I'd rather do on my own time, so I'll not undertake any reading program until they either pay me overtime or give me office time in which to do it." This is on a par with the demand for a bribe before one will agree to vote for a given political candidate.
And if I am so indifferent to the joy of reading, and can see only "their" interest in having me well-read, it raises a serious question as to whether I have any business being in this profession and drawing my salary, however little!

Then there is the "utter futility" alibi, contending that the number and kinds of books which I ought to know about and might like to read are so tremendous that it is just hopeless for me to scratch the surface, far less to delve deeply; therefore, I might as well not attempt it at all. It would be no less absurd to argue that we need not attempt to educate our children, because we can never teach them everything they need to know; or that I would be foolish to save a cent since, out of my meager earnings, I cannot possibly save up a quarter-million dollars in my lifetime. All that is needed, for such a lame apology, is to stare it full in the face-and laugh.

The obverse side of that one is the "sour grapes" alibi: Everything which is being published today is either trash or a rehashing of what someone else said better before; therefore, I, who have already read the World's One Hundred Greatest Books, have little to gain from any further reading, and no problem at all in keeping up with the very few books worth reading. My own experience has been that this line of reasoning is less frequently encountered among librarians than any of the others we have noted. Where it does appear, the only answer is: Then shame on us for accepting money to buy and preserve hypocritically promote what nobody really needs!

These are the favorite and more frequent extenuations I have encountered, though others undoubtedly exist and there are, of course, countless variations and combinations of alibis. But in our catalog of absolutions there must be noted one other attitude of an even more sinister caliber which is observable in varying degrees of purity and intensity. This "extroversional viewpoint" denies 
that there is' any need for or value in a knowledge of the contents and history of books on the part of librarians, precisely because it maintains that the sole, proper function of librarianship is to do things to books or for books, and not to have any feelings about them or personal interest in them. Selection, it contends, is the work of the subject specialist, which the librarian rarely is and should not attempt to be; and use is a private problem of the patron in which the librarian should interfere as little as possible. In between the two, the librarian's job is a purely commercial and technical one: to place orders and pay bills, index and describe for the user's convenience, maintain records and take inventory, and (perhaps) help the user find what he wants if he asks for aid.

If sincerely held, this belief represents a philosophy of library service, rather than a mere apology for not reading, which must be fought, with weapons more effective than logical arguments, by those who hold a somewhat more elevating and long-range view of the librarian's function. As Lawrence Clark Powell remarked to The Library Association of Great Britain in 1957: “. . . bad leadership in recent years ... has led us after the false gods of housekeeping into the desert of jargon. Talking about techniques has become for many a substitute for reading. Too busy to read, they say. Fatal admission, I say, made by those who thereby disqualify themselves as librarians. There is no substitute for reading." 7

We must understand that only insofar as you and I accept the labor of, and responsibility for, acquiring such a knowledge of books as can supplement and, if need be, supplant the work of the subject specialist, and afford a significant and informed service of active aid to the patron, will we be in any position to combat this mechanistic approach and to

7 "Books Will Be Read: Librarv Association Annual Lecture," Library Journal, LXXXIII (1958), 346-51. maintain the professional-intellectual status of librarianship. We need not expect to have others do our work, while we reap the glory-and the reward.

As long as I have not faced and fully rejected all of these specious reasons why I need not read, as long as I keep one or another of these alibis at my elbow for exculpation when the going gets tough and competing interests press hard and I decide to drop my reading activity for the "indefinite present," any reading goal which I may set myself will never amount to much. In The Wonderful World of Books (1952), there is an essay by Louis Shores on "How To Find Time To Read," in which he advocates a consistent, daily program of fifteen minutes devoted to reading. I am not convinced that a ritualistic program of $x$ minutes per day is always possible, or generally sound; but it is clear that there must be an active conscience at work to slap us down if more than three or four consecu. tive days pass with no personal reading accomplished. Such a conscience doesn't stand a chance of survival, while it is in constant danger of being repeatedly anesthetized by these delusive excuses.

\section{THE READING}

A. What. The saving of this uneasy union between librarians and books depends, then, on the former's acceptance of these two articles of faith: that he ought to seek a greater knowledge and understanding of books, and that, while such knowledge must always remain extremely incomplete and uncertain, he is able to learn much more than he now knows. The performance of the ceremony -the awarding of his library degreesymbolized not the end of his education, but its beginning. When he has made that admission, without hypocrisy or constraint, he is ready to start on a lifetime of reading.

But, read what? Start where? On the basis of his own experience, Sir William Haley reports: "I came to the conclusion 
that year in year out 150 books a year is a reasonable average." 8 For almost any librarian, this would represent only 10 per cent at best, and a tiny fraction of one per cent at worst, of the new titles currently received and cataloged by his own library (which is, again, an infinitesimal fraction of the world's current publication)-disregarding entirely, as he cannot afford to do, any retrospective reading of previous acquisitions or rereading of personal favorites which warrant and reward such repetition. The best efforts he can make will therefore be quantitatively selective; and he had better accept this limitation (or frustration) cheerfully.

My own answer to the problem of selection which this realization poses has been: With three exceptions and one qualification, read only what keenly interests you, haphazardly, as it chances to catch your fancy. Three decades of reasonably active reading have completely convinced me of the soundness of Lin Yu-t'ang's observation: "Hence I consider flavor or taste as the key to all reading. It necessarily follows that taste is selective and individual, like the taste for food. ... And if the reader has no taste for what he reads, all the time is wasted. As Yüan Chunglang says, 'You can leave the books that you don't like alone, and let other people read them." 9

To read what I like, so that I am sure to like what I read, may seem like the sheerest self-indulgence; but this is one situation in which I believe indulgence is a wiser course than stern discipline. And here is where my one "qualification" enters in. My likes and interests, within broad limits, are not either predetermined or unalterable. To extend Lin Yu-t'ang's analogy of "flavor or taste" as the key to all reading, my reading predilections resemble my dietary likes and

- A Small Holding on Parnassus (London: Published for the National Book League by Cambridge University Press, 1954), p. 8.

The Importance of Living (New York: Reynal \& Hitcheock, 1937), p. 379. dislikes: they are relatively immutable at the extremes, but highly tractable over the wide range in between. Instead of approaching the world of books with a whole set of hard-and-fast notions as to what I can or cannot stomach, like the spoiled brat who says, "I never ate that before, and I know I don't like it," I can and must adopt a trusting, experimental open-mindedness which welcomes new reading experiences, solicits and considers the recommendations of others, and is constantly searching for new congenialities. Bertrand Russell's formula for "the secret of happiness" is also the surest recipe for happy reading: ". . . let your interests be as wide as possible, and let your reactions to the things and persons that interest you be as far as possible friendly rather than hostile." 10

So Fate and Fancy are the primary criteria determining my current selections, so long as Fancy is understood to be, not wayward, but of a consciously catholic bent, and Fate is thought of, not as predetermination, but as happy chance and natural accident, like the "fate" which brings two strangers together in a lastingly happy marriage. But, as a librarian, I have also accepted three categories of material which I believe ought to be more or less regularly represented among my reading accomplishments, regardless of whether or not they qualify on the score of interest and inclination. I do not like to think of these types as "duty reading"; yet, in scholastic terms, they are almost bound to be closer to required reading than to suggested readings or free electives.

The first of these is the professional literature of librarianship. Far from presuming to prescribe for others, I find that I am still uncertain, even for myself, how much reading of this type $I$ need attempt. I have my own mental reservations as to the practical utility and significance of much of the current

10 The Conquest of Happiness (New York: Horace Liveright, 1930), p. 157. 
voluminous library literature. But certainly there must be a systematic scanning of appropriate journals and, occasionally at least, a careful reading of some articles and certain books. Except for conversations or correspondence with colleagues, or the more drastic, difficult but desirable expedient of numerous jobchanges, this perusal of the professional literature is the only way I know to gain even a partial awareness and appreciation of problems and procedures in other departments of librarianship than one's own. To this end such reading should be less parochial and personal than I suspect it now is for many of us. It should be concerned less with discussions of the topics with which we are already familiar than with questions which are new or strange to us; less with the "Positions Open" columns and news of appointments than with the "Letters to the Editor" and reviews of professional reading. Now and then the latter may, in turn, lead us to some new book which will prove to be pertinent and profitable, and even pleasant reading.

The second category which I accept as requisite is that of books about books: literary essays, criticism and appreciation, subject guides or period surveys, comment on reading and writing. In my experience, such material serves three important purposes.

First, it is suggestive of authors and works I would find congenial. Instead of leaving the discovery of my best-loved books entirely to chance and happy accident, I can enlist the aid of these other avid readers who, in describing their own reactions, will point out one or another title which may serve me either as a point of departure or as an end in itself. Thus, the reading which resulted in my keen and lasting enthusiasm for the writing of Llewelyn Powys began as a direct consequence of L. C. Powell's essay on that essayist.

Secondly, though I do not pursue any further most of the writings discussed in such books-about-books, I still derive from them a certain conversational familiarity - a polite, nodding acquaintance, perhaps-with many more worthwhile books than I ever could encompass on my own. I do not claim that this vicarious acquaintance is just as good as a full reading; but $I$ do insist that it is infinitely better than no acquaintance at all.

And, finally, I derive from this type of publication an important measure of empathy, fraternity, and (to use a somewhat condescending term of our trade) inspiration. For we cannot easily escape the recurrent feeling that ours is a marginal line of endeavor: that our wares, while widely respected, are scarcely in active demand by the majority of our fellows. There are bound to be moments of misgiving (perhaps ten months after our last vacation) when we find ourselves wondering if the work is really worth the effort and actually as important as we claim; times when we feel that we are bucking an inimical society which is prepared to spend millions for cosmetics but not one cent for cosmology! And I have found that from these books about books, I gain the reassurance I need that I am not alone in my feelings towards books and that it is, after all, a rather wonderful and enduring kind of work.

The third of my exceptional classes of material is that of cultural history: the history of art and literature, philosophy and religion, science and technology, commerce and industry, government and economics, education and scholarship, and so on. Of course, I supposedly learned much of this in my undergraduate days, and more of it in library school; but I find that that learning has a disturbing property of evanescence: a strong tendency not to stay learned. Perhaps you are more fortunate; but I have had to accept the necessity for a constant and endless relearning, as well as steady expansion, of my understanding of society: its discoveries, ideas, catastrophies, and 
proclivities. It is not enough for me to know books: I must also know something of the cultural history which tells me when, why, and how they exerted their influence (if any) on the lives of people. It is only through such reading of this sort as I am able to accomplish that I can correlate into a coherent, usable whole the temporally and topically varied balance of my reading.

My "exceptions" may seem like more than a full program in themselves; and, of course, they easily could be. But I have not said (or believed) that they must be voluminously represented among my reading accomplishments: merely more or less regularly. The already accepted limitation, that I can never expect to read more than a minute fraction of what I should or would wish to, applies with even greater force to these three categories than to my preferential reading. I would not allow all three types, collectively, to usurp as much as half of my total reading time for any protracted period.

For, over and over again, experience reinforces my conviction that the reading which does the most lasting good, and the reading of which we make the best use, is the reading which we most enjoy. I regard as the first long step towards intellectual suicide the slavish following of anyone's list of "great" books, or "basic" books, or "favorite" books. He is no real reader who does not gradually compile his own personal and unconventional list. "His personal landscape is mine. And there for me is the whole quest and end of literature: to find and to cherish those works whose vision merges with mine."11

B. How. If I read whatever I like, (and my likes are fairly wide and varied), and constantly strive to broaden my interests, I am still faced with an absurdly impossible amount of reading. But any further load limitations should lie in my manner

11 Powell, Islands of Books (Los Angeles: The Ward Ritchie Press, 1951), p. 111. of attack, and not in greater restriction of scope. I have already indicated that, in my own case, the approach is fortuitous and largely self-indulgent.

There is, first, the matter of finding the right books; but this is no problem. A librarian has four fine opportunities, one or two of which may be his peculiar, professional prerogative, not available to ordinary readers.

1. I examine the flood and flow of books currently acquired by my own library. There are many points along the processing line from receiving room to circulation desk at which this can be done without inconveniencing anyone, if I give just a little consideration to time and technique. The material thus systematically screened will be mostly new publications-but not entirely. Whatever the volume of these current acquisitions, this process should not be arduous or time-consuming; for, if the daily association with books makes any impression on us whatever, it will confer the ability to make some classification and estimation of many of them at merely a glance. Such aspects of physical format as jacket-design, character of type and illustrations, size, binding, and title, will tell us that this volume is a juvenile, that one is a secondary textbook, and some other is a popular historical romance. The greater bulk of the prospects will be eliminated by the use of little more than professional intuition.

For the rest, where this appraisal by externals will not suffice, I use the technique of skimming, or what I prefer to dignify with the name of "sampling analysis." I believe that in most cases I can form an adequately accurate impression of what a book is about, and whether or not it warrants my reading, from just a few moments spent in the preliminary pages, in reading a few scattered paragraphs at random, and even in consulting the jacket "blurb" (always with appropriate correction for editorial bias). I will make mistakes, but they will 
be proportionately very few. And the practice alfords this added, incidental bonus: that in the process of discovering the relatively few books I must really get to know I will gain a cursory introduction to a much larger number. By the time I have sampled sufficiently to know that this volume is not for me I have probably found out a number of other things about it.

When I find a book that is clearly meant for me, I make a note of author and title for future reference, knowing that my memory is not to be trusted; and in this way I soon build up a list which, as the source of a large part of my current reading, becomes a partial record of past and prospective reading in one. It is an inevitable characteristic of this list that, selective as it is and must be, it will increasingly represent far more reading than I shall ever accomplish; for the new additions accumulate much faster than previous entries can be checked off as completed. But it is my insurance against ever wanting for likely, pre-selected suggestions.

2. Periodically, I take time to browse in the stacks. For, after all, I have only been at this library for a few years: I have not been able to inspect every book acquired during that time; and, except for these excursions along the shelves behind the scenes, I would see none of the books acquired before that time. And, unlike many of my confreres, I rather prefer the not-so-brand-new book. I am a very slow reader; and I deliberately eschew the recently reviewed books in heavy demand which can only be allowed to each reader for one week. Reading loses much of its savor for me when it must be performed under a time-limit pressure.

Moreover, unless his job requires a conversancy with the very latest books, I am convinced that any librarian is wise to let a book age a little before he undertakes it. Time itself can be an aid in solving the reading problem. If I wait to read it until a year or two after the book's publication, I sometimes find that I don't need, or care, to read it at all. Then, too, one is sometimes misled by a transient mood: I have had the experience of wondering, on a second examination, how on earth I ever happened even to list the book at its first inspection. Few, if any, books which are really worth my precious reading-time will have become any less so when they are two or three years old than they were at publication.

3. I read reviews, brief bibliographical notices, prospectuses, and catalogs: not comprehensively or systematically but, again, by random selection. Here the resulting service is less in helping me find what I must read than in giving me a short synopsis of many more-or-less discussed books which I need not read.

4. Occasionally I allow my reading itself to suggest further reading. I believe my over-all program should have not only breadth of scope, but intermittent depth, as represented by the more intensive pursuit of a given author or a certain subject. I have come, over recent years, to agree with Sir William Haley that: ". . . there are all kinds of excitement and adventure to be had from associative reading. ... The looser such associative reading is, the better. You will find yourself making the most astonishing, yet seemingly natural, leaps. You will also find that no writer of the first, or even the second, class has worked or lived in complete literary isolation." 12 I may also allow the suggestion of a colleague to put one or another title on my list; but only because he has convinced me that I would enjoy it: never out of a mistaken sense of professional or social duty or obligation.

So the finding of material is easy: it is the reading of any substantial part of what one has found which poses the problem. Hence, I consider it only wise

12 Op. cit., pp. 71-72. 
to let chance and inclination have full sway. I have imposed upon myself no moral obligation to persevere doggedly to the bitter end of any book which fails to "sell itself." Accident, error, or misunderstanding may occasionally place on my list a title which never belonged there. When this becomes clear, the book goes back to the shelf without further waste of time. If it is my kind of book, it will be so more or less from the beginning, and not suddenly become so on page 150. Nor will I submit to any sort of schedule or program: I could not tell you today, with any degree of assurance, what I shall be reading next week; and I would hate to know, myself.

Another characteristic of my undisciplined mode of attack is the practice of keeping three or four or more books in process of being read at any one time. I take my reading time where and when I find it; and I may find it when I am mentally-and temperamentallyeither fresh or stale. With several books under way simultaneously, I can adapt my reading to the mood and means of the moment, and thus make certain that no potential reading time is completely lost.

I have learned, too, to beware of comparing my accomplishments too closely against those of anyone else, especially in any quantitative sense; for this can lead only to discouragement, on the one hand, or intellectual snobbery, on the other, and the mere statistics are not meaningful in themselves. I recognize the fact that $I$ am a slow and painstaking reader and that much of what $I$ accept and enjoy would scarcely qualify as easy reading. I am more concerned with being able to give a clear (not necessarily detailed) account of the essence of the books I have read than I am in keeping score of titles read. And when I come upon a passage which seems to me particularly apt or original, I frequentlv stop to copy it in my vade mecum; for I have found that this is a specially good way of making the book a permanent part of my working equipment.

So, when Haley says that " 150 books a year is a reasonable average," I can admit without any sense of guilt that my own performance is considerably less than this. On the other hand, when a colleague of mine suggests that "a book a month" is enough to qualify a librarian as a reader, I can emphatically disagree. There are limits; but the range is surely very wide, and the rate rarely constant. The volume of my reading, however imposing, will in itself never gain me more than mere notoriety; it is the appropriateness of my selections, and what I have made of them, that will bring the real rewards.

There have been a number of voices raised in advocacy of the application of "remedial reading" measures to this problem of librarians' reading; and there have been a few attempts to put such application into practice. Personally, and on insufficient evidence, I find myself holding a reactionary-even antediluvian-suspicion that the gains to be made in this direction are not entirely sound. But I am open to conviction; and I am sure, with Prof. Burton, that: "Any effort to prevent the disappearance of the well-read librarian is praiseworthy." Speeding up the reading pace is one way of approaching our difficulty, provided it is accompanied by an equivalent acceleration of the processes of assimilation. "But the paradox is that inside a whirl of busyness our minds still work slowly, and our misery is in the unsynchronized disparity. Already considerable masters of linear translation, we are laggard and torpid in thought. Perhaps the only ease this civilization can hope for is not by slowing down but by still more efficient speeding up." 13 In the meantime, I accept my own limitation in this respect and refuse to allow that fact to discourage me or to pass as an excuse for put-

13 Christopher Morley, Historv of an Autumn (Philadelphia: Lippincott, 1938), pp. 71-72. 
ting in less than the maximum possible reading time.

These matters of technique are not presented as the solution. After fair trial, I feel sure that they are the right approach for me, affording a practical balance between freedom and constraint; they may not work for someone else. I cite my attitudes less because they represent one possible answer than because they suggest the questions which must be asked of himself, and answered, by anyone intending to work towards a greater knowledge of books. It might be said with some justice that the only distinguishing feature of my plan is its very planlessness. I only know that with it I have been accomplishing far more reading (though still not half enough) than at any previous period.

One other question is pertinent to this portion of the litigation: the decision to buy or to borrow. Although I would be delighted to own a large, private library, it is clear that the fiscal limitations on my ability to buy are a great deal more drastic than even the temporal limitations on my ability to read. I think that the only books which it is vital for me to own are those relatively few to which I shall want to refer, again and again, (though this, of course, does not mean only that type of compilation known to librarians as "reference works"). Even these I will often begin by borrowing; for I am not sure to recognize these favored few until I have read them once, put them away, and find myself wanting them again. For the substantial balance of my reading, once through is enough; and it is only sensible to borrow. Surely the very least that any library administration can do to foster staff reading is to make its holdings available to all staff members on the best circulation terms accorded to any user. It seems to me entirely proper to expect unlimited-term loan, subject to recall if the book is requested by someone else, with no restrictions on the number of titles allowed.
Yet this freedom to borrow should never be taken for granted by the librarian. It is a prerogative which he should both insist upon having and regard with delighted amazement when he receives. To take such a privilege for granted is a sure sign that "the honeymoon is over."

As a university librarian I am continually aware of the very substantial tuition fees paid by the students, a considerable portion of which is clearly for the right to use the library collection on less advantageous terms than I am accorded, free of all charge! And I am not willing to say that their need is greater than mine.

\section{THE REACTION}

If the first requirement of my adjustment is the refutation of alibis, and the second is the reading itself, the third must be a reaction of some sort. The reading can have done me little good if, when it is over, I have no feeling whatever about the book. The formation of some kind of opinion or set of opinions is surely as essential a part of any adult reading as the correct translation of symbols into sense.

But these reactions are critical judgments which may disclose something about the nature of the book, or may reveal something about the reader. The intuition of this latter possibility makes us reluctant to analyze and articulate the "whys" of our reactions-at times, even to ourselves: we may be exposing some damaging admission that were better left in obscurity. As a result, we understand very little about many of the books we have read, and even less about ourselves; and yesterday's reading is apt to be forgotten tomorrow.

Again, the marriage analogy suggests itself. I come to each new book (polygamously) as a bridegroom to marriage, with certain expectations as to what the experience will afford. I have chosen this mate (or have been chosen and allowed (Continued on page 319 ) 


\section{"As Long As We Both Shall Live"}

(Continued from page 296)

to suppose that I chose) because I think that it is going to help, or comfort, or improve, or amuse, or delight. At the very least, I should know, after a time, whether or not it has met my expectations-and why. To discover this is neither to praise or to damn the book: if the two did not match, it may have been my expectations that were out of line, and not the book.

But, says the newly-wed, this is too personal an experience to be discussed. Quite possibly he may carefully avoid examining his own real feelings in the matter. I have no wish to set up as a maritalrelations counselor; but, in the case of the reading, I am certain that it must be discussed: first in soliloquy; then among friends; and finally with the critic. It is my expectations that are important. If I am consistently satisfied, I am expecting too little, and must raise my standards; if I am consistently disappointed, I am expecting too much, and must come down from my pedestal; if I am consistently bored, I have no expectations, and must set about developing some if I do not intend to become a worthless misfit in the world of books. What is reasonable to expect I determine from my own reading experiences and from the comparison of my expectations with those of others.

The librarian's job is not customarily thought of as embracing the function of critic. The critic is supposed to evaluate; the librarian, to provide, describe, perhaps (if invited) to prescribe, and disseminate. Perhaps the average librarian's reluctance to pronounce judgments (especially, adverse), amounting almost to an occupational disease, is really a nice regard for proper professional boundaries. But, in actual fact, many of our professional activities are, to a considerable extent, critical-no matter how long and loudly we protest our utmost impartiality: cataloging and classification, for example; or the weeding-out of material; or, the most obvious and basic critical judgment of all, selection. The historical development of publishing and library service has carried us over, willy-nilly, into the critic's province; and we are apt to do a better job if we play our part in evaluation in a conscious and conscientious, rather than self-deceptive, manner.

I am unable to understand or sympathize with the false modesty which leads most of us to disparage and conceal our own critical viewpoints because they are amateurish, personal, and prejudiced. All of the most important decisions we make in a lifetime are matters of amateurish, personal, and prejudiced judgment: vocation, religious and political affiliations, marriage and friendships, etc. We make little or no attempt to hide the opinions which these reflect, nor do we feel any need, for the most part, to defend them or excuse them. Why should it suddenly become so different when we are confronted with art, in any of its forms, or philosophy? Is it because we confuse critical opinion with dictum? To say that $I$ like a certain book is not to say that I recommend it indiscriminately to others, or that I predict it will prove to be immortal, or even that I consider it intrinsically better than other books of similar sort and purpose. Even though every practising, professional critic declares an opposite reaction, my pronouncement remains valid within the range in which $I$ have projected it-provided I have taken the pains to say why I find it so. "My reading has always been extremely personal-why deny it?-a hungry search for books to feed my own prejudices, as well as to strengthen my weaknesses, an earnest quest for verifica- 
tion of my own experience." 14 In the pursuit of a greater knowledge of books, it is not just a question of what books are to be known, but of who's knowing them -and how.

\section{THE RELATION}

The best reading efforts I can manage to make, even if I credit myself with "knowing" all those titles I have merely skimmed and rejected or read about in some other book, are going to fall far short of the total knowledge of books I need. Am I in the end and after so much effort, to be defeated in my purpose? I believe that the answer here, as in so many other crucial problems of librarianship, lies to a great degree in cooperation. It is a matter of mild amazement to me that librarians, who have gone so far in cooperative acquisition, cooperative cataloging, cooperative circulation, and cooperative storage, should have done so pathetically little in the way of cooperative reading.

If there are far too many in our professional ranks who would scarcely qualify as readers in any sense, there is a much larger number who read but, having read, seem to consider it a point of honor or duty never to mention the fact in polite society; if they admit the addiction to reading at all, it is only to one or two of their most intimate acquaintances. Since this attitude is completely foreign to my make-up, I cannot claim to understand it; but I suspect that this strange reticence has various motivations: in some cases, the belief that such conversation about books read would prove boring to others; or, perhaps, the fear that what one has read recently would be regarded by others as too trivial to mention or, even worse, as distinctly queer; or, in other instances, the misgiving that what one had to say about a given title might prove to be not the "right" reaction; and so on. In any event,

14 Powell, Islands of Books, p. 54. there is a clearly discernable tradition that any group of librarians, from two to twice two thousand, assembled anywhere outside the library, may discuss salary scales and working conditions, travel experiences and vacation plans, personalities and gossip, movies, sports and TV programs, politics and the weather-anything, except books and reading!

While I shall never accede to this tradition, I am obviously powerless to do much about changing it; yet, I would have you consider what seems to me to be three good reasons why it ought to be changed. The principal one is based upon an observed phenomenon which I have formulated as Sweet's Law of the Natural Diversity of Reading Interests: If you take any group of from six to sixteen reading librarians, and make no effort to influence or mold their instinctive preferences, you will find remarkably little overlapping in their fields of primary interest. One reads science fiction, by choice, and another, detective stories; a third is particularly interested in local history, and a fourth, in music; still another combines an interest in medieval history with a love for modern art, while I claim the essay, and other forms of belles-lettres, as my favored sphere; contemporary English and American fiction has its well-read adherents, and so it goes. If, then, each member of this group is sharing with each other member a running review of his particular reading interests and activities, everyone must derive at least a conversational acquaintance with a tremendously broad scope of material to supplement his more intensive familiarity with certain specific fields. If you contend that such a vicarious, "drawing-room" knowledge of many books is worse than having none at all, I can only record my dissenting opinion. To me it is one further and fruitful way of knowing about a great many more books than we can ever know intimately and directly, and of knowing them bet- 
ter-because of personal associationsthan a bibliographical reference or a paragraph in some guide-to-the-literature would allow.

Theoretically, such exchange of bookknowledge might be either oral (as in group discussion) or written (as in a library-staff publication); and, in either case, it might be either informal (as in an impromptu, ad libitum account) or systematic (as in a prepared speech or paper). After participation in various experiments, I have reluctantly concluded that there is no one "best" approach, and that the situation calls for some use of all possible methods. The main thing is that there should be some constant effort at communication of this sort, even if at the outset it is a responsibility accepted only by a small minority.

The second argument in favor of cooperative reading is that it confers the auxiliary benefit of clarification and coordination of one's own reading. The very effort to formulate my impressions and descriptions of the books I have read in more precise terms that I would ever do for myself alone serves to correct any misconceptions, sharpen vague notions, and relate the diverse reactions I derive from each, and thus makes the books a more permanent yet pliable part of my total working equipment.

And the third reason for such relation of reading experience is its very value as propaganda. Only when some brave (or foolhardy?) souls take the initiative, and figuratively stand up in meeting-house to make their declarations as readers and reactors, will the reluctance of others to do the same be overcome. There is a happy quality of contagion in bibliophilism: as one reader voices his enthusiasms or concerns, he stirs up a like response in listeners who would otherwise have remained silent.

But let us be very clear on one point: any cooperative reading efforts are worse than wasted if they are intended to sell to others $m y$ favorite authors or even $m y$ chosen topics. The aim must be to share -not to convert; there must be not merely tolerance of, but positive respect for others' varying interests and discoveries; and the only permissible proselytism is that on behalf of the general good and the common aim of a greater composite knowledge of books. What is needed is not standardization of reading efforts in any one direction but a widespread individuality of effort, plus the proud, affectionate, unashamed admission of this devotion to books. "To the end I shall be reading-and forgetting. Ah, that's the worst of it! Had I at command all the knowledge I have at any time possessed, I might call myself a learned man. Nothing surely is so bad for the memory as long-enduring worry, agitation, fear. I cannot preserve more than a few fragments of what I read, yet read I shall, persistently, rejoicingly. Would I gather erudition for a future life? Indeed, it no longer troubles me that I forget. I have the happiness of the passing moment, and what more can mortal ask?" 15

The word "relation" has a happy ambiguity which lends a multiple meaning to its use as the theme of this chapter. It can mean: (a) the "act of relating, or telling"; or (b) "the mode in which one thing stands to another"; or (c) the "state of being mutually or reciprocally interested." 16 Because there is a relation, in sense (b) between our individual reading activities, we must develop a relation, in sense (c), by means of a relation, in sense (a). In pioneer fashion, we can help each other, if we will.

\section{THE RECONCILIATION}

And so, while there is still time, I tender these, my reconciliation vows, to my estranged profession, the "calling" of books:

I shall read, in part for profit and in

15 George Gissing, The Private Papers of Henry Ryecroft (New York: The Modern Library. n.d.), p. 45 . ${ }_{10}$ Webster's Collegiate Dictionary (5th ed.; Springfield, Mass.: G. \& C. Merriam Co., c1936), p. 839. 
part for pleasure, as voraciously as determination can manage and as variously as interest allows; I shall read "persistently, rejoicingly."

By reading books about books, and by casual acquaintances with other books, I shall learn about many more books than I am able to know through the actual reading. I shall constantly study the profession, her traits and tendencies, not merely because she is such a fascinating enigma, but because the better I know her the more likely we are to avoid future discord.

I shall form impressions and opinions about the books I read; and, whenever the opportunity arises, I shall voice those views - not arrogantly, yet earnestly.

I shall try to induce my colleagues to give me the benefit of their diverse reading experiences; and, in this, I shall not wait for them to take the initiative, but will begin by discussing my own reading, in the announced expectation that they will respond in kind.

And if they should prove to be unwill- ing to cooperate, I shall not allow this failure to mitigate or cancel the other responsibilities, here undertaken.

Read, react, relate. That is my program: neither a casually simple one, nor yet an impossible or unreasonable goal. And, to the extent that I succeed, I believe that this search for a greater knowledge of books will inevitably be its own reward. "The inquiring mind, the relishing mind, the ever-young (because unsatiated) mind. Books cannot on their own give you these things. It is what you in the first place must-no matter how long you live-be always prepared to give to them. Admittedly they can then return it to you stimulated and heightened, the kind of 'breeder-reactor' effect we now talk about so glibly in this atomic age. But, so far as you are concerned, every masterpiece is dead until you bring it to life." 17 These aims, therefore, I promise to pursue for "as long as we both shall live."

17 Haley, op. cit., pp. 19-20.

\section{Inflation}

A recent study of books in thirteen different subject fields showed that from 194758 the price increase ranged from 47 to 58 per cent. For example, books in the field of science had an average cost of $\$ 5.52$ in 1947 . The average cost in 1958 was $\$ 9.16$. Books in the field of business which had an average cost of $\$ 4.72$ in 1947-49 had an average cost of $\$ 7.98$ in 1958 . Books in the field of history had an average cost of $\$ 4.76$ in $1947-49$ and by 1958 the average cost was $\$ 6.46$.

In the area of U.S. periodical prices, the average cost of periodicals in the field of agriculture in 1947-49 was $\$ 1.77$, and in 1958 the average cost was $\$ 2.48$. .

According to information obtained from a leading library supply house, there has been a 38 per cent over-all increase in all items since 1950 .

In 1945 the average salary of all public library employees (part time, full time, professional, clerical, building staff, etc.) was $\$ 1,100$. In 1956 the amount was $\$ 2,230$....

Beginning salaries of library school graduates have risen from an average of $\$ 3,675$ in 1954 to $\$ 4,693$ in 1958 , an increase of about 27 per cent. . - - From $U$. $S$. Congress. House. Committee on Education and Labor. Subcommittee on Special Education. Extension of Library Services Act. Hearings, 86th Cong., $2 d$ sess., on H.R. 9319, H.R. 9494, H.R. 9812. Washington: 1960. p. 8. 